\title{
Effects of trace elements and current densities on denitrification, microbe growth, ATP generation and enzyme activity in a bio- electrochemical reactor
}

\author{
Hengyuan Liu ${ }^{1}$, Qili Hü ${ }^{2}$ Nan Chen ${ }^{3}$, Chuanping Feng ${ }^{3, *}$ \\ ${ }^{1}$ College of Chemistry and Life Sciences, Chifeng University, Chifeng 024000, China \\ ${ }^{2}$ College of Ecology and Environment, Chengdu University of Technology, Chengdu 610059, China \\ ${ }^{3}$ School of Water Resources and Environment, China University of Geosciences (Beijing), Beijing \\ 100083, China \\ *E-mail: $\underline{\text { ChuanpingFeng@outlook.com }}$
}

Received: 13 July 2021 / Accepted: 25 August 2021 / Published: 10 November 2021

\begin{abstract}
This study explored the effects of trace elements and current densities on denitrification, microbe growth, ATP generation, and enzyme activity in a bio-electrochemical reactor (BER). The optimum current density of $200 \mathrm{~mA} / \mathrm{m}^{2}$ and the addition of trace elements significantly improved the nitrate removal efficiency compared with the control $(99.9 \%$ versus $85.2 \%)$ and remarkably reduced the intermediate nitrite accumulation $(4.01 \pm 0.03$ versus $8.25 \pm 0.35 \mathrm{mg} / \mathrm{L})$. A microbial study showed that the application of the optimum current density and trace elements promoted the microbial growth, ATP activity, cell membrane permeability and denitrification key enzyme activity. An elemental analysis revealed that iron and molybdenum significantly improved the catalytic activity of nitrate reductase (Nar), while iron and copper enhanced the catalytic activity of nitrite reductase (Nir). This study provides an important insight into the potential effects of using an optimum current density and trace elements on denitrifying microorganisms and the denitrification performance within a bio-electrochemical reactor BER.
\end{abstract}

Keywords: Bio-electrochemical reactor (BER); Trace elements; Electro-stimulation; Denitrification key enzyme activity; Microbial growth

\section{$\underline{\text { FULL TEXT }}$}

(C) 2021 The Authors. Published by ESG (www.electrochemsci.org). This article is an open access article distributed under the terms and conditions of the Creative Commons Attribution license (http://creativecommons.org/licenses/by/4.0/). 